\title{
Teaching Practices of the Mathematics Male and Female Teachers According to the PISA Framework and its Relation to their Beliefs towards their Students
}

\author{
Ahmad Shaleh, Student, Department of Instructional Technology, Universitas Negeri Malang, Jl. Semarang No. 5 \\ Malang, Jawa Timur, Indonesia, zakaria@unisma.ac.id ,Orcid no: 0000-0003-0540-4672 \\ Ibrahim Khalil, Professor, Department of Instructional Technology, Faculty of Education, Universitas Negeri \\ Malang, Indonesia, punaji.setyosari.fip@um.ac.id, Orcid no: 0000-0003-0187-9785 \\ Yousef Wardat, Doctor, Department of Instructional Technology, Faculty of Education, Universitas Negeri \\ Malang, Indonesia, dedi.kuswandi.fip@um.ac.id, Orcid no: 0000-0003-1005-6641 compulsory
}

\begin{abstract}
The study aimed to identify the different teaching practices of mathematics male and female teachers according to the framework of PISA 2018 and its relation to their beliefs towards their students. The study used the descriptive survey approach. The sample consisted of (421) mathematics male and female teachers in AL-Taif city in the year $1442 \mathrm{AH}$. After testing the reliability and validity; two tools were used to collect data: a questionnaire and a scale. Results showed that both genders, male and female teachers, have a high level of formulation of mathematics; the mean was (2.4840). Moreover, their teaching practices level of employing mathematics was high and reached the mean (2.3976). Meanwhile their level of teaching practices of the process of mathematics explanation was at the mean (2.2130). Results also showed that there is a statistical significant difference in the level $(\alpha \leq 0,05)$. The previous result is related to the gender variable in which females outperformed the males, and to the teaching experience in which the more experienced respondents outperformed the inexperienced ones. Finally, results showed that there was no statistical significant difference in the level $(\alpha \leq 0,05)$ for the level of education variable. Based on the results of the study, the following recommendations might be taken into consideration: workshops might be hilled to improve the teachers' teaching practices of mathematics formulation and explanation in addition to some steps and procedures in PISA framework must be embedded in the teacher's guide.
\end{abstract}

Keywords: Teaching Practices, PISA, Math Beliefs

Received: $15.11 .2020 \quad$ Accepted: 11.12.2020 $\quad$ Published: 16.01 .2021

\section{INTRODUCTION}

Mathematics is one of the most important sciences that are relied upon in developing societies because of its importance in developing thinking and solving life problems that these societies are exposed to on the daily basis (Khalil and Al-Nazir, 2019). Mathematics contributes to preparing the creative thinker individual facing daily problems; thus, mathematics is considered one of the pillars building and maintaining society (Al-Sharifat and Al-Ghunaimat, 2016). The Ministry of Education paid attention to the content of the mathematics curriculum, a matter which contributes to the students' confrontation with their daily problems and the teachers' development to provide assistance.

Mathematics teacher is considered the main pillar in the process of mathematics teaching and learning. Although he is one of its inputs, he has an effective role which is even limited to the kind and quality of this science. As soon as he enters the classroom and stands in front of his students, he is the only one who is able to invest all available resources to achieve their learning goals (Obaid, 2016). In view of the teacher's role in raising the level of his students in order to achieve the aspirations and ambitions of society and the wise vision of 2030 in creating a generation that competes with his peers at the global level. So, it requires him to raise the level of his teaching practices in line with modern trends in the field of teaching and learning mathematics.

The international directions and competitions in the area of mathematics vary; some of them are the international studies carried out by the organizations aiming to help countries in identifying the strong and the weak points of the education systems, so that those countries can improve them. Moreover, they present the scientific processes for improving teaching and learning mathematics in the general stages through 
presenting recommendations depending on the results of those studies that use questionnaires for the teacher, the family, and tests for the students.

One of these organizations is the Organization for Economic Cooperation and Development (OECD), which was founded in 1961, with headquarters in Paris, and currently has 37 members (countries). It aims to formulate policies that promote prosperity in cooperation with governments and citizens and the exchange of experiences and best practices between countries (OECD).

Believing in the importance of mathematics in the individuals' life, the organization (Program for International Student Assessment) provides (PISA) approach which was executed for the first time in the year (2000), and is periodically executed every 3 years. The idea of the approach came out of discussions among the member states of the Organization for Cooperation and Development in the mid-nineties while discussing the need for dependable information about their teaching systems; then the approach was declared in 1997. The main idea of this approach is to carry out an evaluative study of the acquired knowledge in three phases: reading, mathematics, and science. It was targeted to students at the age of 15 years old which is considered the age in which the student ends his obligatory teaching. The mathematical content in PISA exams contains four domains: emptiness and shape, variation and relation, amounts, and uncertainty (Almikhlafi 2010, Neidorf; Binkley, Gattis \& Nohara, 2006).

The program aims to evaluate knowledge, skills, and trends that reflect the current changes in educational curricula, and measures students' ability to employ knowledge in their life situations. It also aims to compare students and the educational system with their peers in other participating countries, and measures the impact of development programs and the level of the educational environment which supports educational decision-makers (Evaluation Commission of Education and Training, 2019).

The PISA test does not only assess whether students can reproduce knowledge. Rather, it examines the extent to which students can extrapolate from what they have learned, and can apply this knowledge in unfamiliar circumstances inside and outside school. This approach is a reflection of the fact that modern economies do not reward individuals for what they know, but rather for what they can do with what they know; in PISA 2018 test, students' proficiency in an innovative field was assessed, that is the global competence. The PISA assessment provides three main types of results: indicators of students' knowledge and skills, indicators derived from questionnaires that show how these skills are related to various demographic, social, economic and educational variables, and trend indicators that show changes in the results and their distribution. PISA results have a high degree of validity and reliability. The PISA 2018 test was conducted primarily by computer as it was for the first time in 2015. Paper-based testing tools were provided to countries that did not want to test their students by computer; but the paper-based test was limited to reading, math, and science items only (i.e. those items that were already used in previous paper-based assessments). As a result, only the new items were developed for the computer-based assessment (OECD, 2019). PISA introduces mental processes according to three developmental stages for the implementation of solving mathematical problems, a matter which indicates that PISA aims to analyze a mental process that exists for everyone without cultural exception (Al-Mikhlafi, 2010). The test focuses on Mathematical Literacy, which is defined by the Organization for Economic Cooperation and Development (OECD, 2013) as the ability to use and employ mathematics in different contexts including the use of concepts, procedures, facts and the ability to reasoning, describe, explain and predict the phenomenon. The Organization for Economic Cooperation and Development (OECD, 2019) also defines it as the ability of an individual to formulate, employ and interpret mathematics in a variety of contexts. This includes mathematical thinking, the use of mathematical concepts, procedures, facts and tools to describe, interpret and predict various phenomena, a matter which helps him to realize the role that mathematics plays in building him as a good citizen in his community able to make correct decisions based on right foundations.

The previous definitions refer to three main terms that are: formulation, employment and interpretation of mathematics. OECD (2019) referred to a matrix called the relationship between mathematical operations and main mathematical abilities clarifying those terms as explained in the following table: 
Table 1: The relationship between mathematical operations and basic mathematical abilities.

\begin{tabular}{|c|c|c|c|}
\hline & $\begin{array}{l}\text { Formulating } \\
\text { attitudes } \\
\text { Mathematically }\end{array}$ & $\begin{array}{l}\text { Employing } \\
\text { concepts, facts, } \\
\text { and procedures, } \\
\text { and } \\
\text { mathematical } \\
\text { thinking }\end{array}$ & $\begin{array}{l}\text { Interpreting, applying, and } \\
\text { evaluating mathematical } \\
\text { results }\end{array}$ \\
\hline Communication & $\begin{array}{l}\text { Read, interpret and } \\
\text { understand } \\
\text { statements, } \\
\text { questions, tasks, } \\
\text { objects, and images, } \\
\text { in order to form a } \\
\text { mental model of the } \\
\text { situation }\end{array}$ & $\begin{array}{l}\text { Explain the } \\
\text { solution, review } \\
\text { the steps followed } \\
\text { to reach a solution } \\
\text { and / or } \\
\text { summarize and } \\
\text { present } \\
\text { intermediate } \\
\text { mathematical } \\
\text { results }\end{array}$ & $\begin{array}{l}\text { Build and provide } \\
\text { explanations and evidence in } \\
\text { the context of the problem }\end{array}$ \\
\hline Mathematical handling & $\begin{array}{l}\text { Identify relevant } \\
\text { mathematical } \\
\text { variables and } \\
\text { structures in the } \\
\text { real problem, and } \\
\text { make assumptions } \\
\text { so that they can be } \\
\text { used }\end{array}$ & $\begin{array}{l}\text { Use understanding } \\
\text { context to direct or } \\
\text { accelerate the } \\
\text { process of solving } \\
\text { a mathematical } \\
\text { problem (for } \\
\text { example, working } \\
\text { towards a level of } \\
\text { precision } \\
\text { appropriate to the } \\
\text { context) }\end{array}$ & $\begin{array}{l}\text { Understanding the extent } \\
\text { and limits of a mathematical } \\
\text { solution which are Outputs } \\
\text { of the used mathematical } \\
\text { model }\end{array}$ \\
\hline Representation & $\begin{array}{l}\text { Create a } \\
\text { mathematical } \\
\text { representation of } \\
\text { information about a } \\
\text { real problem }\end{array}$ & $\begin{array}{l}\text { Interpret, relate, } \\
\text { and use a variety of } \\
\text { representations } \\
\text { when interacting } \\
\text { with the problem }\end{array}$ & $\begin{array}{l}\text { Interpret, relate, and use a } \\
\text { variety of representations } \\
\text { when interacting with the } \\
\text { problem. Compare and } \\
\text { evaluate two or more } \\
\text { representations of the } \\
\text { situation }\end{array}$ \\
\hline Reflection and Argument & $\begin{array}{l}\text { Clarify, defend, and } \\
\text { provide } \\
\text { justification for a } \\
\text { specific or } \\
\text { substantive } \\
\text { representation of a } \\
\text { realistic situation }\end{array}$ & $\begin{array}{l}\text { Clarify, defend and } \\
\text { provide } \\
\text { justification for the } \\
\text { processes and } \\
\text { procedures used to } \\
\text { determine the } \\
\text { mathematical } \\
\text { outcome } \\
\text { solution. } \\
\text { Connect pieces of } \\
\text { information to } \\
\text { come up with a } \\
\text { mathematical } \\
\text { solution }\end{array}$ & $\begin{array}{l}\text { Make generalizations or } \\
\text { create a multi-step proof or } \\
\text { argument. Reflect on } \\
\text { mathematical solutions and } \\
\text { develop explanations and } \\
\text { proofs to support, disprove, } \\
\text { or make a mathematical } \\
\text { solution appropriate to a } \\
\text { contextual problem }\end{array}$ \\
\hline
\end{tabular}




\begin{tabular}{|c|c|c|c|}
\hline $\begin{array}{l}\text { Develop strategies } \text { for } \\
\text { problem solving }\end{array}$ & $\begin{array}{l}\text { Choose or develop a } \\
\text { plan or strategy to } \\
\text { reframe contextual } \\
\text { problems }\end{array}$ & $\begin{array}{l}\text { Activate or } \\
\text { activate effective } \\
\text { and continuous } \\
\text { control } \\
\text { mechanisms } \\
\text { through a multi- } \\
\text { step procedure } \\
\text { that leads to a } \\
\text { mathematical } \\
\text { solution, } \\
\text { conclusion, or } \\
\text { generalization }\end{array}$ & $\begin{array}{l}\text { Create and implement a } \\
\text { strategy for interpreting, } \\
\text { evaluating and } \\
\text { demonstrating } \\
\text { mathematical solution to a } \\
\text { contextual problem }\end{array}$ \\
\hline $\begin{array}{l}\text { Use of symbolic, formal and } \\
\text { artistic language and } \\
\text { processes }\end{array}$ & $\begin{array}{l}\text { Use appropriate } \\
\text { variables, symbols, } \\
\text { graphs and models } \\
\text { to represent a } \\
\text { realistic problem } \\
\text { using symbolic / } \\
\text { formal language }\end{array}$ & $\begin{array}{l}\text { Understand, and } \\
\text { use formal } \\
\text { concepts based on } \\
\text { formal definitions, } \\
\text { rules, and systems } \\
\text { and also employ } \\
\text { algorithms }\end{array}$ & $\begin{array}{l}\text { Understand the relationship } \\
\text { between the problem } \\
\text { context and the } \\
\text { representation of a } \\
\text { mathematical solution. Use } \\
\text { this understanding to help } \\
\text { interpret the solution in } \\
\text { context and gauge the } \\
\text { feasibility and potential } \\
\text { limits of the solution }\end{array}$ \\
\hline Use of mathematical tools & $\begin{array}{l}\text { Use mathematical } \\
\text { tools in order to } \\
\text { distinguish } \\
\text { mathematical } \\
\text { structures or } \\
\text { review } \\
\text { mathematical } \\
\text { relationships }\end{array}$ & $\begin{array}{l}\text { You must know } \\
\text { and be able to } \\
\text { properly use the } \\
\text { various tools that } \\
\text { may help in } \\
\text { applying } \\
\text { operations and } \\
\text { procedures to } \\
\text { determine } \\
\text { mathematical } \\
\text { solutions }\end{array}$ & $\begin{array}{l}\text { Use mathematical tools to } \\
\text { ensure the rationality of the } \\
\text { mathematical solution and } \\
\text { any limitations or } \\
\text { restrictions on this solution } \\
\text { based on the context of the } \\
\text { problem }\end{array}$ \\
\hline
\end{tabular}

Table (1) indicates that the formulation of mathematics is intended to identify opportunities for employing mathematics in various contexts. It is the study of situations or problems and formulating them mathematically in preparation for solving them, identifying the variables and providing the necessary mathematical representations and assumptions that help in solving the problem. As for the employment of mathematics, it is intended to identify opportunities for employing mathematics in various contexts: to employ mathematical ideas, facts, procedures and justifications, to use mathematical concepts, facts, procedures and tools, to perform numerical and algebraic calculations, and to use mathematical models. Applying mathematical reasoning to solve problems, it includes mathematical treatment, the use of mathematical concepts, facts, procedures, and mathematical tools, the performance of calculations, the use of algebraic expressions, equations and other mathematical models, and the analysis of information using mathematical drawings and figures. As for the interpretation of mathematics, it means the interpretation, application and evaluation of mathematical outputs, and it means contemplation of mathematical solutions or results, their interpretation in the context of the situation or the problem, its evaluation and the study of its logic and plausibility.

Mathematics culture is considered as one of the components in building 21st century skills (Rizki; Priatna, 2018). A mathematically educated person is characterized by his great ability to use the mathematical knowledge and skills he possesses in facing his daily problems, making the right decision and understanding all the phenomena that revolve around him, as well as his constant knowledge of everything new in the field of mathematics (Abd al-Rahman, 2017).

Several studies were conducted on the framework of the PISA tests. A study by Mersal (2016) concluded that the level of mathematics culture among students of the College of Education was low. The study 
recommended the importance of including a course on the vocabulary of mathematics culture and methods for its development among students, and the appropriate tools to measure it. Obaidah (2017) aimed to identify the effectiveness of a teaching model based on PISA activities in developing the components of mathematics mastery and confidence among first-grade secondary school students. The study reached to a set of results; the most important of which are: There were statistically significant differences at the level of $(\alpha \leq 0,01)$ in the level of mathematical mastery and confidence in mathematics in favor of the experimental group. The study recommended taking into account the components of mathematical prowess and including them in the objectives of mathematics teaching and learning, in addition to including experiences and activities that support the development of mathematical mastery. The study of Ambarita; Asri; Agustina; Octavianty \& Zulkardi (2018) referred to the description of mathematical modeling skills in solving PISA problems. Based on the results of the study, the sample was divided into three categories (good, sufficient, and bad). A good category; they can identify important variables in the matter or situation; While in the sufficient category, they cannot use the variables; And in the bad category, they cannot define and use variables. Whereas in the process of employing mathematics, students in the good category can use the concept, truth, procedure, and proof. In the sufficient category, they use the concept and the truth but cannot use the procedure and the proof. In the bad category, they cannot use concept, truth, procedure, and proof. In the process of interpreting mathematics, students in the good category can think of solutions, result, and conclude. In the sufficient category, they can think of a solution and an outcome, but not come to a conclusion; whereas in the bad category, they cannot think of the solution, the result, and the conclusion. Al-Migbil $(2019, \mathrm{~A})$ aimed to determine the level of mathematics culture and its sub-processes formulation, employment and interpretation among first-grade secondary school students in Riyadh in accordance with the framework of PISA. The study concluded that the levels of female students are below the required level for success. The study recommended the establishment of training programs to develop mathematics culture among female students. The study of AL-Migbil $(2019, \mathrm{~b})$ aimed to present a proposed course in mathematics culture and knowing its effectiveness in developing mathematics culture among first-grade secondary school students. The study found that there is a statistical significant difference at the level of $(\alpha \leq 0,05)$ for the experimental group in the domains of formulation of mathematics, employment of mathematics, and interpretation of mathematics. The study recommended the importance of taking into account the mathematical culture in the decisions of the various stages, the importance of including realistic problems, and the inclusion of paragraphs in the tests according to the PISA framework.

Since the teacher is concerned with the advancement of students' levels in general and the level of mathematics culture in particular, his beliefs about his students which have an important influence on his teaching practices must be studied. Oshoush (2015) stresses the importance of studying teachers' beliefs as they represent an entry point for developing classroom practices and makes them in line with modern trends in mathematics education as confirmed by the study of both Al-Naqbi and Al-Sawai (2006) and Al-Harthi (2008) who emphasize that there is a positive relationship between teachers' beliefs and classroom practices. Cross (2019) believes that how a teacher perceives mathematics, has a direct impact on its teaching. He also asserts that if we want to develop teacher practices, teacher's beliefs must be addressed first. Cross also defines beliefs as a set of conscious and unconscious thoughts and perceptions of an individual's self and his place in the world around him developed through his social relationships. Tarawneh and Khasawneh (2018) define beliefs as a system of ideas, opinions, and perceptions that overlap among themselves and that teachers carry them towards the nature of mathematics and its teaching and learning. Teachers' beliefs can be defined as teachers' perceptions and opinions about the components of the educational process.

Many studies have focused on studying the teachers' beliefs in general and teachers of mathematics in particular. Cross (2009) aimed at studying the relationship between teachers' beliefs and their classroom practices. The study confirmed that teachers' general beliefs were highly influential on their daily educational decisions and that their beliefs about the nature of mathematics were a primary source for their beliefs about pedagogy and student learning. Oshoush (2015) aimed at identifying the extent of consistency in primary school mathematics teachers' beliefs and classroom practices regarding the use of learning by playing. The study found that there is no statistically significant correlation in the level of $(\alpha \leq 0.05)$ between teachers' beliefs about the use of learning by playing and their classroom practices for it. On the other hand, the study of Khalil and Al-Maliki (2017) aimed to identify the factors that affect mathematics teachers and make them form positive beliefs about their teaching competence before and after service. The study concluded that the field education and specialized mathematics courses are among the most prominent factors affecting mathematics teachers before their service, as for the most important factors affecting after their service. For the most 
important programs affecting them after service are the professional development programs and a teacher's guide. Melody; Ariadna; Natalia; \& Raquel (2020) aimed at revealing the beliefs of the student and the teacher about teaching and learning mathematics. The study concluded that teaching and learning of mathematics should enhance the understanding of the topic and the active participation of the students, a matter which facilitates their discovery. Results also showed the presence of Euclidean beliefs, followed by mixed beliefs. In the same context, León-Mantero, Camino and Franandise-Caesar; Pinto; Camino; \& Fernández-Cézar (2020) aimed at identifying teachers' beliefs, anxiety and teaching practices of primary education teachers. Results showed that teachers' beliefs are mainly either euclidean or quasi-experimental beliefs towards mathematics. With a high concern about mathematics, teachers use the process of reasoning and proof followed by solving problems most of their variables come from mathematical operations.

While previous studies tried to study the relationship between mathematics teachers' beliefs and their teaching practices, whether in general or about using a specific method, the idea of the current study appeared to design teaching practices in accordance with the framework of PISA 2018 and its relationship with the beliefs of mathematics male and female teachers towards their students.

\section{Problem of Research}

The Ministry of Education in the Kingdom of Saudi Arabia made distinct and continuous efforts during the academic year $1441 \mathrm{AH}$. It aimed at contributing to raising the level of student achievement in general and in international and national tests in particular. It provided many training courses and educational leaflets on international tests, but the results of participation in the 2018 PISA exams showed a general weakness in mathematical abilities. As the Kingdom of Saudi Arabia is ranked among the countries with the lowest achievement rates in mathematics, the general average for participants reached (373) while the international average was (489). Al-Migbil study (2019, A) found that mathematics culture and its sub-processes formulation, employment and interpretation among female students of the first grade of secondary school in Riyadh according to the framework of PISA below the level required for success. In view of the teacher's role in improving the level of his students, many studies were conducted to assess the level of his teaching performance including the Ruwais study (2016); and AL-Qarni (2019) which concluded that the level of practices did not live up to expectations especially the teaching skills that develop engineering thinking skills and solve mathematical problems. The studies of Ruwais, Al-Shalhoub and Ab Dal Hamid and Al Badour (2016); and Khalil (2016) indicated that the level of mathematics teachers' practices in linking mathematical concepts with life problems, and the use of higher thinking skills in teaching mathematics was average. It recommended providing activities related to the student's life. The study of Al-Tamran and Khalil (2019) found that the level of mathematics teachers 'practices in presenting mathematics activities in the form of social contexts was "sometimes" at a low level. While Mersal study (2016) recommended educating teachers about the importance of raising the level of mathematics culture among students, especially in the general education stage.

In addition to the studies above, and according to the researchers' field experience and what they observed of the low level of students in the mathematical operations adopted in the framework of PISA, in addition to the need to spread the culture of developing teaching practices in light of recent trends and international tests, the researchers decided to conduct a more in-depth study that begins with extracting teaching practices according to the PISA framework, and then identifying the level of teaching practices of mathematics male and female teachers from their point of view and identifying the extent of their relevance to their beliefs towards their students.

\section{Questions of the study:}

The current study sought to answer the following questions:

\section{The first main question}

What is the level of teaching practices for mathematics male and female teachers in accordance with the framework of PISA 2018?

The following sub-questions are divided into:

The first sub-question: What is the level of teaching practices of mathematics male and female teachers in formulating mathematics according to the PISA 2018 framework?

The second sub-question: What is the level of teaching practices of mathematics male and female teachers in employing mathematics according to the PISA 2018 Framework? 
The third sub-question: What is the level of teaching practices of mathematics male and female teachers in interpreting mathematics according to the PISA 2018 Framework?

\section{The second main question}

What are the beliefs of mathematics male and female teachers towards their students according to the requirements of the field of operations within the framework of PISA 2018?

\section{The third main question}

Is there a statistically significant relationship between the level of teaching practices of mathematics male and female teachers and their beliefs towards their students in light of the PISA 2018 framework?

\section{Hypotheses of the study}

There are no statistically significant differences in the level $(\alpha \leq 0.05)$ between the opinions of the sample members regarding the level of teaching practices due to the variables of gender, teaching experience, and qualification.

\section{Objectives of the study}

The current study tried to achieve the following objectives:

1. Identify the level of teaching practices for mathematics male and female teachers in accordance with the framework of PISA 2018.

2. Exposing the correlation between the teaching practices of mathematics male and female teachers in accordance with the framework of PISA 2018 and their beliefs towards their students in it.

3. Detection of statistically significant differences in the level $(\alpha \leq 0.05)$ between the teaching practices of mathematics male and female teachers according to the framework of PISA 2018 according to the variables (gender, teaching experience, and qualification).

\section{Significance of studying}

The significance of the study stems from:

1- Presenting a list of teaching practices derived from the mathematics culture processes in accordance with the framework of PISA 2018.

2- Providing feedback to officials in the Ministry of Education about teaching practices according to PISA 2018.

\section{Limitations of the study}

\section{Topic limitations}

The study is limited to identifying the level of teaching practices of mathematics male and female teachers in accordance with the framework of PISA 2018, and their relationship to their beliefs towards their students.

\section{Spatial boundaries}

The study is limited to governmental schools for boys and girls in the Kingdom of Saudi Arabia affiliated to ALTaif Education Department.

\section{Time boundaries}

The study is applied in the first semester of the academic year $1442 \mathrm{AH}$.

\section{Definitions of terms}

\section{Teaching practices according to the framework of PISA 2018}

Al-Maliki and Al-Selouli (2018) define teaching practices as "all the activities and procedures that a mathematics teacher does at the elementary stage during the teaching position to provide educational material with the aim of effecting learning among the learners and changing their behavior in accordance with the objectives of the curriculum."

Teaching practices according to the framework of PISA 2018 are procedurally defined as all the activities and procedures that a male and female mathematics teacher, in the stages of general education, do 
during the teaching position to provide the educational material and achieve the goals of the curriculum and reach with male and female students to a high level in the processes of mathematical culture (formulation of mathematics - employment of mathematics - interpretation of mathematics). According to the framework of PISA 2018, they are measured through a questionnaire for a teacher prepared for this purpose.

\section{Math teacher beliefs}

Kim, Sihn; and Mitchell ( 2014) define beliefs as teacher's views on his competence and ability to perform specific math teaching tasks at a certain level of quality in the school context.

It is operationally defined as the views of the mathematics male and female teachers towards the ability and competence of their students in formulating, employing and interpreting the different mathematical situations related to the mathematical content about the ability of their students to be able to perform procedures aimed at the practices of male and female teachers to achieve them for their students; these practices are in light of the mathematical culture processes (forming mathematics - employing mathematics interpretation of mathematics). According to the framework of PISA 2018, they are measured through a teacher questionnaire prepared for this purpose.

\section{METHOD}

\section{Participants}

The study sample reached (421) male and female teachers who represent $16.1 \%$ of the population of the study. The following table shows the sample of the study according to the variables of the study:

Table 1. Distribution of the sample of the study according to its variables

\begin{tabular}{|l|l|l|}
\hline Variable & Kind & Number \\
\hline \multirow{2}{*}{$\begin{array}{l}\text { Gender } \\
\text { Qualification }\end{array}$} & Male & 234 \\
\cline { 2 - 3 } & Female & 187 \\
\cline { 2 - 3 } & Bachelor & 378 \\
\hline \multirow{3}{*}{ Experience } & Higher education & 43 \\
\cline { 2 - 3 } & 10 years or less & 167 \\
\cline { 2 - 3 } & More than 10 years & 254 \\
\hline
\end{tabular}

It is evident from table (2) that the number of the study sample is (421) in total. while the number of males is (234) teachers, representing (44.4\%), the number of females is (187) and represent (55.6\%) of the sample members. Participants with a bachelor's degree were (378), representing (89.8\%) of the study sample, and the number of participants with higher degrees was (43), representing (10.2\%). Regarding the variable of teaching experience, the number of participants whose service was 10 years or less was (167). They represent (39.7\%) of the study sample. On the other hand, the number of participants with more than 10 years of experience reached (254) participants representing $(60.3 \%)$.

\section{Two study tools}

Given the aim of the study, which is to identify the level of teaching practices of mathematics male and female teachers and their beliefs towards their students, the study used two tools:

\section{First: The questionnaire}

The aim of the study was to identify the level of the teachers' teaching practices in accordance with the framework of PISA 2018, and it was built after passing several stages, namely:

1- Viewing the general framework of PISA 2018.

2- Access to the studies that dealt with the international exams of PISA, including: Mersal study (2016), Obaidah study (2017), and Ambarita; Asri; Agustina; Octavianty \& Zulkardi study (2018), AL-Migbil study (2019, a), and AL-Migbil study $(2019, \mathrm{~b})$.

3- Sending an electronic questionnaire to a group of people interested in international studies framework PISA with the aim of monitoring a set of practices consistent with the processes of culture and mathematics in accordance with the framework of PISA 2018. 
4- Building the tool in its initial form, then presenting it to a group of referees and experts in the field of mathematics education to tale their opinions.

5- Access to the final image of the tool, including a scale of appreciation for each practice according to a triple gradient (high, medium, and low), as it came as follows:

The first axis: teaching practices in the formulation of mathematics and consists of nine paragraphs.

The second axis: teaching practices in employing mathematics and consists of nine paragraphs.

The third axis: teaching practices in the interpretation of mathematics and consists of six paragraphs.

1- The level of teaching performance:

To determine the periods of performance levels, a score was assigned to each level. Where the high level was determined as (3), the medium level was rated (2), and the low level was ranked (1), the range was calculated as follows:

Table 3. An example of a scale of appreciation for a teaching practice according to the PISA 2018 Framework

\begin{tabular}{|c|c|c|c|}
\hline \multirow[t]{2}{*}{ Teaching Practice } & \multicolumn{3}{|l|}{ Self-evaluation } \\
\hline & High (3) & Mid (2) & Low (1) \\
\hline $\begin{array}{l}\text { I direct my students to } \\
\text { use symbols to express } \\
\text { mathematical concepts. }\end{array}$ & $\begin{array}{l}\text { I present situations } \\
\text { and experiences } \\
\text { related to the } \\
\text { lesson concept. I } \\
\text { direct students to } \\
\text { use mathematical } \\
\text { symbols by } \\
\text { following and } \\
\text { during class and } \\
\text { providing feedback }\end{array}$ & $\begin{array}{l}\text { I present earliest conceptual } \\
\text { situations and experiences } \\
\text { with students using } \\
\text { mathematical symbols }\end{array}$ & $\begin{array}{lr}\text { I use mathematical } \\
\text { symbols to express } \\
\text { concepts } & \\
\text { referring to } & \end{array}$ \\
\hline
\end{tabular}

\section{The level of teaching performance}

To determine the periods of performance levels, a score was assigned to each level; where the high level was determined as (3), the medium level was rated (2), and the low level was ranked (1), the range was calculated as follows:

$3-1 \div 3=66$. Which represents the length of the period, and the division of the periods was as follows:

Table 4. Judgment periods on performance levels for teaching practices.

\begin{tabular}{|l|l|}
\hline Level & Duration \\
\hline High & $2.34-3$ \\
\hline Middle & $1.67-2.33$ \\
\hline Low & $1-1.66$ \\
\hline
\end{tabular}

\section{Tool validity}

The tool was presented to a group of teachers, supervisors and experts in the field of mathematics education in order to know their opinions about the tool in terms of: the integrity of the formulation, its relationship to the processes according to the PISA 2018 framework, its appropriateness, and the relevance of the sub-clauses to the main axes. In light of the opinions of the referees, some of its paragraphs were amended and others were deleted to produce the tool in its final form; the paragraphs that received an agreement of $85 \%$ were approved.

\section{Tool Reliability}

The stability of the tool was calculated using Cronbach's alpha, and the results were as follows:

Table 5. Calculation of the stability of the tool axes and the total stability of the tool.

\begin{tabular}{|l|l|l|}
\hline Level & Axes Title & Stability rate \\
\hline One & Mathematics formulation & $84 \%$ \\
\hline Two & Mathematics employment & $89 \%$ \\
\hline
\end{tabular}




\begin{tabular}{|l|l|l|}
\hline Three & Mathematics interpreting & $84 \%$ \\
\hline The overall performance & $94 \%$ \\
\hline
\end{tabular}

It is clear from Table (5) that the stability rate for the first axis: Mathematics formulation is (0.84), the stability rate for the second axis: Mathematics employment is (0.89), and the stability rate for the third axis is (0.84). The stability rate for the tool as a whole is $(0.94)$ which is an acceptable reliability statistical rate..

Second: The scale of mathematics males and females teachers' beliefs towards their students according to the PISA 2018 framework:

Since the aim of the scale is to identify the beliefs of mathematics male and female teachers towards the abilities of their students according to the requirements of the Pisa operations (formulation, employment, interpretation), the teaching practices questionnaire was used and its formulation was directed in accordance with the goal of the tool as in the following example:

Table 6. A sample to demonstrate the relationship between phrasing as a teaching practice and belief about students' abilities in light of the Pisa framework (2018).

\begin{tabular}{|l|l|}
\hline Phrase as a teaching practice & $\begin{array}{l}\text { The phrase as a teacher's belief } \\
\text { towards the abilities of his students }\end{array}$ \\
\hline $\begin{array}{l}\text { I direct my students to make } \\
\text { assumptions to solve the problem }\end{array}$ & $\begin{array}{l}\text { My students can make assumptions to } \\
\text { solve the problem. }\end{array}$ \\
\hline
\end{tabular}

\section{Statistical tests}

Due to the multiple objectives of the study, the following statistical tests were used:

1- Frequencies, percentages, arithmetic means, and standard deviations to learn about the level of teaching practices according to the PISA 2018 framework and teachers' beliefs towards their students.

2- T-test of two independent samples was used to identify the significance of differences in practices and beliefs according to the study variables (gender, teaching experience).

3- Pearson correlation coefficient was used to identify the level of correlation between the teaching practices of mathematics male and female teachers according to the PISA 2018 Framework, and their beliefs towards their students.

\section{RESULTS, DISCUSSION AND INTERPRETATION}

To answer the first question of the study: What is the level of teaching practices of mathematics male and female teachers according to PISA 2018 Framework?, the sub-questions were answered. They were as follows:

The first sub-question: What is the level of teaching practices of mathematics male and female teachers in formulating mathematics according to PISA 2018 framework?. To answer the question, the frequencies, the arithmetic mean, and the standard deviation were calculated for each statement within the axis, and Table (7) shows that in details.

Table 7. Response of respondents to the expressions of the first axis, frequencies, arithmetic means and standard deviations of the responses of the sample members for the first axis: the formulation of mathematics

\begin{tabular}{|c|c|c|c|c|c|c|c|c|}
\hline \multicolumn{9}{|c|}{ The first axis: teaching practices in the formulation of mathematics } \\
\hline \multirow[t]{2}{*}{ NO. } & \multirow[t]{2}{*}{ Teaching practice } & \multicolumn{3}{|c|}{ Self-evaluation } & \multirow[t]{2}{*}{ mean } & \multirow{2}{*}{$\begin{array}{l}\text { Standard } \\
\text { Deviation }\end{array}$} & \multirow{2}{*}{$\begin{array}{l}\text { Level of } \\
\text { performance }\end{array}$} & \multirow[t]{2}{*}{ Ranking } \\
\hline & & high & mid & low & & & & \\
\hline 1. & $\begin{array}{l}\text { I direct my students } \\
\text { to read the } \\
\text { mathematical } \\
\text { problem well. }\end{array}$ & 18 & 90 & 313 & 2.70 & 0.544 & High & 1 \\
\hline 2. & $\begin{array}{l}\text { I stimulate my } \\
\text { students to identify }\end{array}$ & 19 & 137 & 256 & 2.58 & 0.578 & High & 2 \\
\hline
\end{tabular}




\begin{tabular}{|c|c|c|c|c|c|c|c|c|}
\hline & $\begin{array}{l}\text { the data and what } \\
\text { is required in the } \\
\text { problem. }\end{array}$ & & & & & & & \\
\hline 3. & $\begin{array}{l}\text { I motivate my } \\
\text { students to identify } \\
\text { variables relevant } \\
\text { to the problem. }\end{array}$ & 26 & 170 & 256 & 2.47 & 0.611 & High & 5 \\
\hline 4. & $\begin{array}{l}\text { I direct my students } \\
\text { to make } \\
\text { assumptions to } \\
\text { solve the problem. }\end{array}$ & 38 & 157 & 226 & 2.45 & 0.655 & High & 6 \\
\hline 5. & $\begin{array}{l}\text { My students were } \\
\text { given a } \\
\text { mathematical } \\
\text { representation of } \\
\text { the problem }\end{array}$ & 41 & 187 & 193 & 2.36 & 0.653 & High & 9 \\
\hline 6. & $\begin{array}{l}\text { I discuss with my } \\
\text { students about } \\
\text { their mathematical } \\
\text { representation of } \\
\text { the problem. }\end{array}$ & 44 & 163 & 214 & 2.40 & 0.671 & High & 7 \\
\hline 7. & $\begin{array}{l}\text { I direct my students } \\
\text { to create a } \\
\text { problem-solving } \\
\text { plan. }\end{array}$ & 37 & 141 & 243 & 2.49 & 0.653 & High & 4 \\
\hline 8. & $\begin{array}{l}\text { I give students the } \\
\text { opportunity to } \\
\text { provide } \\
\text { justifications for } \\
\text { their plans to solve } \\
\text { the problem }\end{array}$ & 47 & 165 & 209 & 2.38 & 0.679 & High & 8 \\
\hline 9. & $\begin{array}{l}\text { I direct my students } \\
\text { to use symbols to } \\
\text { express } \\
\text { mathematical } \\
\text { concepts }\end{array}$ & 33 & 139 & 249 & 2.51 & 0.638 & High & 3 \\
\hline \multicolumn{2}{|c|}{$\begin{array}{l}\text { The overall average for an } \\
\text { axis: math formulation }\end{array}$} & \multicolumn{5}{|c|}{2.4840} & \multicolumn{2}{|l|}{ High } \\
\hline
\end{tabular}

It is clear from table (7) that the level of teaching practices in the focus of mathematics formulation from the point of view of sample was (high). The averages ranged between (2.36) and (2.70) with a general average for the axis (2.4840). The teaching practice of "my students' reading the problem well" came with the highest average reaching (2.70). It is easy to identify them so that he can solve them. This is due to the diversity and multiplicity of mathematical problems included in the curricula which usually carry different ideas calling for urging students to read well. The practice "motivate my students to define the data and what is required in the problem" was in the second order, with a high level and an average of (2.58). The required data from the question of the teaching practice "was made available to my students to put a mathematical representation of the problem" was the lowest average reaching (2.36). This is due to the insufficient time for the class to put a mathematical representation of each problem in the class in some lessons, whether for poor planning of the lesson or for the large number of students in the classroom. This is also attributed to the teacher's focus on the basics of the classroom, and the scarcity of items that require the student to do mathematical representation where it is sometimes contained in a paragraph trained in the textbook within several paragraphs. The results of this study are consistent with Khalil's study (2016) which concluded that providing students with the opportunity to justify their answers came at a high level, and with the Al-Qarni study (2019) which concluded 
with the low level of teaching practices that develop mathematical problem-solving skills, and also with ALRuwais study (2016) that have reached a low level of teaching practices that develop engineering thinking skills.

The second sub-question: What is the level of teaching practices of mathematics male and female teachers in employing mathematics according to PISA 2018 framework?. To answer the question, the frequencies, the arithmetic mean, the standard deviation were calculated for each phrase within the axis. Table (8) shows that in detail:

Table 8. Response of sample members to the expressions of the first axis, frequencies, arithmetic means and standard deviations of the responses of the sample members to the first axis: Employment of mathematics

\begin{tabular}{|c|c|c|c|c|c|c|c|c|}
\hline \multicolumn{9}{|c|}{ The second axis: teaching practices in employing mathematics } \\
\hline \multirow[t]{2}{*}{ NO. } & \multirow[t]{2}{*}{ Teaching practice } & \multicolumn{3}{|c|}{ Self-evaluation } & \multirow{2}{*}{$\begin{array}{l}\text { mea } \\
\mathrm{n}\end{array}$} & \multirow{2}{*}{$\begin{array}{l}\text { Standa } \\
\text { rd } \\
\text { Deviat } \\
\text { ion }\end{array}$} & \multirow{2}{*}{$\begin{array}{l}\text { Level of } \\
\text { performance }\end{array}$} & \multirow{2}{*}{$\begin{array}{l}\text { Rank } \\
\text { ing }\end{array}$} \\
\hline & & high & mid & $\begin{array}{l}\text { lo } \\
\text { w }\end{array}$ & & & & \\
\hline 1. & $\begin{array}{l}\text { I discuss with my } \\
\text { students about their } \\
\text { solving procedures. }\end{array}$ & 21 & 109 & $\begin{array}{l}29 \\
1\end{array}$ & 2.64 & 0.575 & High & 1 \\
\hline 2. & $\begin{array}{l}\text { I motivate my } \\
\text { students to speed up } \\
\text { the process of } \\
\text { drawing conclusions. }\end{array}$ & 32 & 173 & $\begin{array}{l}21 \\
6\end{array}$ & 2.44 & 0.632 & High & 3 \\
\hline 3. & $\begin{array}{l}\text { I direct my students } \\
\text { to link mathematical } \\
\text { relationships that } \\
\text { contribute to solving } \\
\text { the problem. }\end{array}$ & 51 & 68 & $\begin{array}{l}20 \\
2\end{array}$ & 2.36 & 0.688 & High & 5 \\
\hline 4. & $\begin{array}{l}\text { I allow my students to } \\
\text { use the appropriate } \\
\text { mathematical tools. }\end{array}$ & 44 & 153 & $\begin{array}{l}24 \\
4\end{array}$ & 2.34 & 0.674 & High & 4 \\
\hline 5. & $\begin{array}{l}\text { I direct my students } \\
\text { to use their previous } \\
\text { concepts related to } \\
\text { mathematical } \\
\text { problem solving. }\end{array}$ & 47 & 131 & $\begin{array}{l}24 \\
3\end{array}$ & 2,47 & 0.688 & High & 2 \\
\hline 6. & $\begin{array}{l}\text { I introduce my } \\
\text { students to using } \\
\text { algorithms in a logical } \\
\text { sequence. }\end{array}$ & 57 & 158 & $\begin{array}{l}20 \\
6\end{array}$ & 2.35 & 0.708 & High & 6 \\
\hline 7. & $\begin{array}{l}\text { I ask my students to } \\
\text { mention situations in } \\
\text { their lives in which } \\
\text { they can benefit from } \\
\text { the concepts of the } \\
\text { lesson. }\end{array}$ & 62 & 168 & $\begin{array}{l}19 \\
1\end{array}$ & 2.31 & 0.713 & mid & 8 \\
\hline 8. & $\begin{array}{l}\text { I motivate my } \\
\text { students to critique } \\
\text { their peer solutions } \\
\text { procedures. }\end{array}$ & 67 & 173 & $\begin{array}{l}18 \\
1\end{array}$ & 2.27 & 0.719 & mid & 9 \\
\hline 9. & $\begin{array}{l}\text { I stimulate my } \\
\text { students to model } \\
\text { mathematical } \\
\text { problems. }\end{array}$ & 48 & 195 & $\begin{array}{l}17 \\
8\end{array}$ & 2.31 & 0.665 & mid & 7 \\
\hline
\end{tabular}




\begin{tabular}{|l|l|l|}
\hline $\begin{array}{l}\text { The overall average for the } \\
\text { axis: employing math }\end{array}$ & 2.3967 & High \\
\hline
\end{tabular}

As clear in table (8), the level of teaching practices in the axis of employing mathematics from the viewpoint of the sample was (high). Where the averages ranged between (2.64) and (2.27) and a general average for the axis reached (2.3967). The teaching practice "I discuss with my students about the procedures for their dissolution" came with the highest average reaching (2.64) due to the interest of teachers in reaching the conceptual and procedural depth. This supports the textbook's inclusion of solved activities supported by justifications for the solution steps. The teaching practice, "I stimulate my students to criticize the procedures of their peers' solutions, "came as the lowest average, reaching (2.27), due to the lack of class time in exchange for the number of lessons and students inside the classroom. This is due to the teachers' focus on the basic activities that start with a component of the lesson. The peer evaluation activities are included in the section on higher thinking skills, a matter which is supported by Al-Ruwais et al. study (2016) which indicated that mathematics teachers' use of higher thinking skills was at an intermediate level. The results of this study are consistent with the study of Al-Tamran and Khalil (2019) study which concluded that the level of practices of mathematics male and female teachers in presenting mathematical activities in the form of social contexts was at a level "sometimes"., and with Oshoush (2015) in which the practice of "the teacher opens the way for students to evaluate their colleagues," came to a small degree.

The third sub-question: What is the level of teaching practices of mathematics male and female teachers in interpreting mathematics according to PISA 2018 framework? To answer the question, the frequencies, the arithmetic mean, and the standard deviation were calculated for each statement within the axis. Table (9) shows that in detail.

Table 9. Response of sample members to the expressions of the first axis, frequencies, arithmetic means and standard deviations of the responses of the sample members for the first axis: Interpretation of mathematics

\begin{tabular}{|c|c|c|c|c|c|c|c|c|}
\hline \multicolumn{9}{|c|}{ The second axis: teaching practices in employing mathematics } \\
\hline \multirow[t]{2}{*}{ NO. } & \multirow[t]{2}{*}{ Teaching practice } & \multicolumn{3}{|c|}{ Self-evaluation } & \multirow[t]{2}{*}{ mean } & \multirow{2}{*}{$\begin{array}{l}\text { Standard } \\
\text { Deviation }\end{array}$} & \multirow{2}{*}{$\begin{array}{l}\text { Level of } \\
\text { performance }\end{array}$} & \multirow[t]{2}{*}{ Ranking } \\
\hline & & high & mid & low & & & & \\
\hline 1. & $\begin{array}{l}\text { I direct my students } \\
\text { to reflect on the } \\
\text { solution. }\end{array}$ & 60 & 153 & 208 & 2.35 & 0.717 & High & 1 \\
\hline 2. & $\begin{array}{l}\text { I direct my students } \\
\text { to interpret the result } \\
\text { in several formats. }\end{array}$ & 74 & 186 & 161 & 2.21 & 0.719 & mid & 3 \\
\hline 3. & $\begin{array}{l}\text { I motivate my } \\
\text { students to provide } \\
\text { justifications for a } \\
\text { solution. }\end{array}$ & 92 & 150 & 179 & 2.21 & 0.776 & mid & 4 \\
\hline 4. & $\begin{array}{l}\text { I debate with my } \\
\text { students about the } \\
\text { plausibility of a } \\
\text { solution. }\end{array}$ & 84 & 152 & 185 & 2,24 & 0,763 & mid & 2 \\
\hline 5. & $\begin{array}{l}\text { I direct my students } \\
\text { to interpret given } \\
\text { mathematical } \\
\text { representations. }\end{array}$ & 86 & 180 & 155 & 2,16 & 0.740 & mid & 5 \\
\hline 6. & $\begin{array}{l}\text { I guide my students } \\
\text { to predict according } \\
\text { to the outcome of a } \\
\text { problem. }\end{array}$ & 101 & 173 & 147 & 2.11 & 0.761 & mid & 6 \\
\hline \multicolumn{2}{|c|}{$\begin{array}{l}\text { The overall average for the } \\
\text { axis: interpreting math }\end{array}$} & \multicolumn{5}{|c|}{2.2130} & \multicolumn{2}{|l|}{ Mid } \\
\hline
\end{tabular}


It is clear from Table (9) that the level of teaching practices in the axis of mathematics interpretation from the viewpoint of the sample was (average). The averages ranged between (2.35) and (2.11) and the general average for the axis was (2.2130). The teaching practice of "I direct my students to reflect on the solution "came with the highest average, reaching (2.35). This is due to the interest of male and female teachers in developing critical thinking skills among their students through depth. The teaching practice "I direct my students to predict according to the outcome of a problem" came as the lowest average, reaching (2.11) due to it being a higher thinking skill that does not fit all levels of students. The result of the present study is consistent with the result of Khalil (2016) in practice related to students' discussion of the plausibility of a solution, and Oshoush (2015) study in the practice related to the teacher's interest in students' ideas and discussion, as it came to an average level.

The second question: What are the beliefs of mathematics male and female teachers towards their students according to the requirements of the field of operations within the framework of PISA 2018?

To answer the question, the frequencies, the arithmetic mean, and the standard deviation were calculated for each statement within the axis. Table (10) shows that in detail.

Table 10. Response of respondents to the expressions of the first axis, frequencies, arithmetic averages and standard deviations of individuals' responses to their beliefs towards their students according to the field of operations according to the PISA 2018 framework

\begin{tabular}{|c|c|c|c|c|c|c|}
\hline \multicolumn{7}{|c|}{$\begin{array}{l}\text { The first axis: the beliefs of mathematics male and female teachers in the standard of } \\
\text { mathematics formulation }\end{array}$} \\
\hline \multirow[t]{2}{*}{ NO. } & \multirow{2}{*}{ Indicator } & \multicolumn{3}{|c|}{ Response } & \multirow[t]{2}{*}{ mean } & \multirow{2}{*}{$\begin{array}{l}\text { Standard } \\
\text { Deviation }\end{array}$} \\
\hline & & Agree & $\begin{array}{l}\text { Neutra } \\
l\end{array}$ & Disagree & & \\
\hline 1. & $\begin{array}{l}\text { My students can read the } \\
\text { problem well. }\end{array}$ & 28 & 149 & 244 & 2.51 & 0.619 \\
\hline 2. & $\begin{array}{l}\text { My students are able to } \\
\text { determine the data and } \\
\text { what is needed in the } \\
\text { problem. }\end{array}$ & 39 & 155 & 227 & 2.45 & 0.658 \\
\hline 3. & $\begin{array}{l}\text { My students are able to } \\
\text { identify variables related } \\
\text { to a problem. }\end{array}$ & 53 & 193 & 175 & 2.29 & 0.677 \\
\hline 4. & $\begin{array}{l}\text { My students can make } \\
\text { assumptions to solve the } \\
\text { problem. }\end{array}$ & 61 & 146 & 214 & 2.36 & 0.723 \\
\hline 5. & $\begin{array}{l}\text { My students have the } \\
\text { ability to develop a } \\
\text { mathematical } \\
\text { representation of a } \\
\text { problem. }\end{array}$ & 59 & 179 & 183 & 2.29 & 0.699 \\
\hline 6. & $\begin{array}{l}\text { My students defend their } \\
\text { mathematical } \\
\text { representation of the } \\
\text { problem very efficiently. }\end{array}$ & 67 & 198 & 156 & 2.21 & 0.697 \\
\hline 7. & $\begin{array}{l}\text { My students can create a } \\
\text { problem-solving plan. }\end{array}$ & 46 & 162 & 213 & 2.40 & 0.677 \\
\hline 8. & $\begin{array}{l}\text { My students justify their } \\
\text { plans to solve the problem. }\end{array}$ & 44 & 173 & 204 & 2.38 & 0.668 \\
\hline 9. & $\begin{array}{l}\text { My students can use } \\
\text { symbols to express } \\
\text { mathematical concepts. }\end{array}$ & 52 & 145 & 224 & 2.41 & 0.700 \\
\hline \multicolumn{2}{|c|}{$\begin{array}{l}\text { The overall average for an axis: } \\
\text { math formulation }\end{array}$} & \multicolumn{5}{|l|}{2.36} \\
\hline
\end{tabular}




\begin{tabular}{|c|c|c|c|c|c|c|}
\hline \multicolumn{7}{|c|}{$\begin{array}{l}\text { The second axis: the beliefs of mathematics male and female teachers in the standard of } \\
\text { employing mathematics }\end{array}$} \\
\hline 1. & $\begin{array}{l}\text { My students defend their } \\
\text { solving procedures very } \\
\text { efficiently. }\end{array}$ & 28 & 161 & 232 & 2.48 & 0.619 \\
\hline 2. & $\begin{array}{l}\text { My students have the } \\
\text { power to speed up the } \\
\text { process of drawing } \\
\text { conclusions. }\end{array}$ & 45 & 200 & 176 & 2.31 & 0.655 \\
\hline 3. & $\begin{array}{l}\text { My students can relate } \\
\text { mathematical } \\
\text { relationships } \\
\text { contribute to solving a } \\
\text { problem. }\end{array}$ & 64 & 178 & 179 & 2.27 & 0.710 \\
\hline 4. & $\begin{array}{l}\text { My students have the } \\
\text { ability to use appropriate } \\
\text { mathematical tools. }\end{array}$ & 58 & 164 & 199 & 2.33 & 0.707 \\
\hline 5. & $\begin{array}{l}\text { My students can use their } \\
\text { previous concepts related } \\
\text { to mathematical problem } \\
\text { solving. }\end{array}$ & 56 & 158 & 207 & 2.36 & 0.705 \\
\hline 6. & $\begin{array}{l}\text { My students can use } \\
\text { algorithms in a logical } \\
\text { sequence. }\end{array}$ & 76 & 154 & 191 & 2.27 & 0.749 \\
\hline 7. & $\begin{array}{l}\text { My students mention } \\
\text { situations in their lives in } \\
\text { which they can benefit } \\
\text { from the concepts of the } \\
\text { lesson. }\end{array}$ & 55 & 174 & 192 & 2.33 & 0.694 \\
\hline 8. & $\begin{array}{l}\text { My students can critique } \\
\text { their peer resolution } \\
\text { procedures. }\end{array}$ & 57 & 168 & 196 & 2.33 & 0.702 \\
\hline 9. & $\begin{array}{l}\text { My students have the } \\
\text { ability to model } \\
\text { mathematical problems. }\end{array}$ & 54 & 200 & 167 & 2.27 & 0.674 \\
\hline \multicolumn{2}{|c|}{$\begin{array}{l}\text { The overall average for an axis: } \\
\text { Employing math }\end{array}$} & \multicolumn{5}{|c|}{2.33} \\
\hline \multicolumn{7}{|c|}{$\begin{array}{l}\text { The third axis: the beliefs of mathematics male and female teachers in the standard of } \\
\text { mathematics interpretation }\end{array}$} \\
\hline 1. & $\begin{array}{l}\text { My students can ponder } \\
\text { the solution. }\end{array}$ & 70 & 144 & 207 & 2.33 & 0.744 \\
\hline 2. & $\begin{array}{l}\text { My students can interpret } \\
\text { the result in several } \\
\text { formats. }\end{array}$ & 84 & 190 & 147 & 2.15 & 0.726 \\
\hline 3. & $\begin{array}{l}\text { My students are able to } \\
\text { provide justifications for } \\
\text { their solutions. }\end{array}$ & 77 & 180 & 164 & 2.21 & 0.729 \\
\hline 4. & $\begin{array}{l}\text { My students can check the } \\
\text { reasonableness of the } \\
\text { solution. }\end{array}$ & 87 & 168 & 166 & 2.19 & 0.753 \\
\hline 5. & $\begin{array}{l}\text { My students have the } \\
\text { ability to interpret given } \\
\text { mathematical } \\
\text { representations. }\end{array}$ & 93 & 179 & 149 & 2.13 & 0.747 \\
\hline
\end{tabular}




\begin{tabular}{|l|l|l|l|l|l|l|}
\hline 6. & $\begin{array}{l}\text { My students can predict } \\
\text { the outcome of a problem. }\end{array}$ & 100 & 193 & 128 & 2.07 & 0.734 \\
\hline $\begin{array}{l}\text { The overall average for an axis: } \\
\text { math interpreting }\end{array}$ & 2.18 \\
\hline The overall average of the scale & 2.31 \\
\hline
\end{tabular}

It is evident from table (10) that the average beliefs of mathematics male and female teachers towards the abilities of their students in light of the framework of PISA 2018 operations reached in general to (2.31). The axis of mathematics formulation came with the highest average, reaching (2.36), while the average of the axis of employment of mathematics was (2.33). This is due to the fact that mathematics interpretation is an advanced stage of higher thinking skills, so the male and female teachers' beliefs about it among their students was the least average. Regarding the first axis: Mathematics Formulation: The general average for the axis came (2.36) as the averages of the paragraphs varied between (2.51) and (2.21). The paragraph "My students can read the problem well" came with the highest average, and this is consistent with teachers' practices, which came as the highest teaching practice. Regarding the paragraph "My students defend their mathematical representation of the problem with high efficiency." Came as the lowest average. This is attributed to the weakness in including the sections of the tests that the teacher prepares for higher thinking skills that require mathematical justification. Regarding the second axis: employing mathematics: the general average for the axis came (2.33), where the averages of the paragraphs varied between (2.48) and (2.27). The paragraph "My students defend their solving procedures with high efficiency" came as the highest average, and this is consistent with the result of the first question, where the practice was the highest average in the axis. regarding the paragraph "My students have the ability to model mathematical problems" came as the lowest average due to the scarcity of activities that call for mathematical modeling, whether in the curricula or in the tests designed by the teachers. As for the third axis: the interpretation of mathematics: the general average for the axis came (2.18), whereas the averages of the paragraphs varied between (2.33) and (2.07). The paragraph: "My students can reflect on the solution." came as the highest average with the paragraph "My students can predict according to the outcome of a problem,". This is due to the scarcity of mathematical situations in school curricula that call for prediction.

The result of the current study differs in the belief regarding the employment of mathematics in life from the study of Oshoush (2015). As it came in the current study at a medium level, it came in the study of Oshoush at a strong level, as well as in terms of employing symbols, shapes and mathematical tools.

The third question: Is there a statistically significant relationship between the level of teaching practices of mathematics male and female teachers and their beliefs towards their students in light of the PISA 2018 framework?. To answer this question, the Pearson correlation coefficient was calculated between the level of teaching practices and beliefs, and the results were as shown in Table (11):

Table 11. The value of the Pearson Correlation Coefficient to identify the level of relationship, the level of teaching practices and beliefs towards students.

\begin{tabular}{|l|l|l|l|l|}
\hline Variables & Sample & $\begin{array}{l}\text { Correlation } \\
\text { coefficient }\end{array}$ & $\begin{array}{l}\text { Level of } \\
\text { significance }\end{array}$ & Significance \\
\hline $\begin{array}{l}\text { Teaching practices } \\
\text { Beliefs towards } \\
\text { students }\end{array}$ & 421 & 0.678 & 0.000 & Significant \\
\hline
\end{tabular}

Table (11) shows that the value of the Pearson correlation coefficient reached (0.678), which is a statistically significant value at the level $(\alpha \leq 0,05)$. This means that, according to the framework of Pisa, there is a correlation between the teaching practices of mathematics male and female teachers and their beliefs towards their students. The correlation appeared in several situations. The first axis: formulation of mathematics: the practice "my students' aspects of reading the mathematical problem well" came as the highest average in the paragraph "My students can read the mathematical problem well." In the second axis: formulation of mathematics: the practice "I discuss with my students about their solving procedures" came as the highest average. Also, the teachers' belief towards their students came in the paragraph "My students defend their solving procedures" with high efficiency. In the third axis: the interpretation of mathematics: the practice "my 
students' aspects to predict according to the outcome of a problem, " came as the lowest average. Also, the teachers' belief towards their students came in the paragraph "My students can predict according to the outcome of a problem" as the lowest average. The most difference appeared between practices and beliefs in the practice "motivate my students to identify the variables related to the problem" as it was at a high level and averaged (2.47), whereas the belief "my students could identify the variables related to the problem" came at an average level and reached an average of (2.29).

The results of the present study are consistent with the results of Al-Naqbi and Al-Sawai (2006). AlHarthi (2008); Cross (2009); and Oshoush (2015) studies which concluded that there is an association between teaching practice and beliefs. It differs with the study of Tarawneh and Khasawneh (2018) study which confirmed the lack of compatibility between teachers' beliefs and teaching practices.

\section{The fourth question}

Are there statistically significant differences at the level of significance $(\alpha \leq 0,05)$ between the opinions of the sample members due to the study variables (gender, teaching experience, qualification)? To answer this question, the following hypothesis was tested:

Hypothesis: There are no statistically significant differences at the level $(\alpha \leq 0,05)$ between the opinions of the sample members regarding the level of teaching practices due to the variables of gender, teaching experience and qualification. To examine the hypothesis, the researchers used (t-test) for two independent samples. Table (11) shows that.

Table 12. A t-test for two independent samples to identify the differences in the opinions of the sample members according to the study variable (Gender).

\begin{tabular}{|l|l|l|l|l|l|l|}
\hline Variable & $\begin{array}{l}\text { Variable } \\
\text { type }\end{array}$ & Number & Mean & $\begin{array}{l}\text { standard } \\
\text { deviation }\end{array}$ & $\begin{array}{l}\text { T } \\
\text { value }\end{array}$ & $\begin{array}{l}\text { Level of } \\
\text { sig. } \\
(\alpha \leq 0,05)\end{array}$ \\
\hline Gender & male & 187 & 2.2286 & 0.35559 & 7.209 & 0.000 \\
\cline { 2 - 5 } & female & 234 & 2.5073 & 0.42235 & & \\
\hline \multirow{2}{*}{$\begin{array}{l}\text { Teaching } \\
\text { experience }\end{array}$} & $\begin{array}{l}10 \text { years or } \\
\text { less }\end{array}$ & 167 & 2.2495 & 0.39902 & 5.527 & 0.000 \\
\cline { 2 - 5 } & $\begin{array}{l}\text { More than } \\
10 \text { years }\end{array}$ & 254 & 2.4716 & 0.40624 & & \\
\hline \multirow{2}{*}{ Qualification } & Bachelor & 378 & 2.3776 & 0.42184 & 0.855 & 0.393 \\
\cline { 2 - 4 } & $\begin{array}{l}\text { Higher } \\
\text { certificates }\end{array}$ & 43 & 2.4351 & 0.37602 & & \\
\hline
\end{tabular}

Table (12) shows a (T) value calculated between the mean of male and female responses that is equal to (7.209), which is a statistical significant difference at the level $(\alpha \leq 0.05)$. This leads to rejecting the null hypothesis, which means that there is a statistical significant difference between the mean of male and females responses in favor of females. The study differs with the study of Al-Tamran and Khalil (2019) which found that there were no differences in practices attributed to the variable of Gender. The (T) value was calculated between the average responses of those with a bachelor's degree and higher degrees and was (0.855) which is not a statistical significant difference at the level $(\alpha \leq 0.05)$. This leads to accepting the null hypothesis, which means that there is no statistical significant difference among the average responses of those who hold a bachelor's degree and higher degrees. The (T) value was calculated among the average responses from their teaching experience "ten years and less" and "more than 10 years" and was (5.527). this is a statistical significant difference at the level of $(\alpha \leq 0,05)$, a matter which leads to rejecting the null hypothesis. This means that there is statistical significant difference among the average responses of those whose teaching experience of ten years and less and more than 10 years. The results of the current study are consistent with the results of Khalil (2016) and Al-Tamran and Khalil (2019) who found differences in teaching practices in favor of teachers with higher experience (10 years or more). But, it differs with Oshoush's study (2015) which concluded that there are no statistically significant differences attributed to the teaching experience. 


\section{RECOMMENDATIONS}

Based on the results of the study, the following recommendations can be made:

- Holding training workshops for mathematics teachers to upgrade their teaching practices in mathematics interpretation and to emphasize their teaching practices in formulating and employing mathematics.

- The teacher's guide should include procedures and steps consistent with operations of the Pisa framework.

- Benefiting from the current study and the results and lists of teaching practices in training and evaluating the teachers' performance.

- Include sections of the Pisa exams in school tests and lessons.

\section{SUGGESTIONS}

Based on the results of the study, the following proposals can be submitted:

- Conducting studies to identify the level of teaching practices of mathematics male and female teachers for each academic stage separately.

- Conducting studies to identify the level of mathematics education processes among students targeted by Pisa tests.

\section{REFERENCES}

Al-Harthi, Ali Salem (2008): The relationship between science teachers' beliefs about the use of an inquirybased learning strategy and their classroom practices for it, unpublished Master's thesis, College of Education, Sultan Qaboos University, Sultanate of Oman.

Abdulrahman, Madiha Hassan (2017): Mathematical enlightenment as an indicator of the quality of teaching and learning mathematics, Mathematics Education Journal, 20 (3), 6-31.

Al-Maliki, Imad and Al-Selouli, Misfer (2018). The level of teaching practices of mathematics teachers at the primary stage in light of standards for teaching and learning mathematics, Journal of Mathematics Education, 21 (2), 135-195.

Al-Mikhlafi, Tawfiq (2010). Large-Scale International Assessment Studies (TIMSS- PIRLS- PISA) A Comparative Analysis of Objectives, Curriculum, Content and Their Cultural Implications, Riyadh: Bureau of Education for the Arab Gulf States.

Al-Miqbil, Munira Abdulaziz (2019, A). The level of mathematical education among first-grade secondary school students in Riyadh according to the framework of Pisa, the Sixth Conference on Teaching and Learning Mathematics.

Al-Miqbil, Munira Abdulaziz (2019, b). The effectiveness of a proposed course in developing the mathematical culture of first-grade secondary school students and its perceptions towards mathematics according to the PISA framework, unpublished PhD thesis, King Saud University, College of Education.

Al-Naqbi, Ali Khalfan, and Al-Sawai, Othman Nayef (2006). Connecting Mathematics and Science, Teachers' Beliefs and Practices in United Arab Emirates Schools, Journal of Studies in Curricula and Teaching Methods, (118), 19-129.

Al-Otaibi, Sarah and Al-Ruwais, Abdulaziz (2016). Teaching practices of mathematics teachers and their relationship to the development of engineering thinking skills among middle school students, Mathematics Education Journal, 19 (1), pp. 151-182.

Al-Qarni, Reem (2019). Enabling mathematics teachers with the necessary teaching competencies to develop skills in solving mathematical problems in the fourth grade of primary school, Mathematics Education Journal, 22 (2), 49-79.

Al-Ruwais, Abdulaziz bin Muhammad and Al-Shalhoub, Samar Bint Abdulaziz and Abdul Hamid, Abdul-Nasser Muhammad and Al-Badour, Ahmed Hassan (2016). The reality of implementing mathematics teachers in the elementary stage to the question of higher thinking skills. International Journal of Educational Research, 40 (1), 29-57.

Al-Sharafat, Hussein; and Ghunaimat, Musa (2016). Mathematics curriculum reality and hope. Amman. Dar AlMu'taz for Publishing and Distribution.

Al-Tamran, Omar Saad and Khalil, Ibrahim Al-Hussein (2019). Teaching practices of mathematics teachers in light of the requirements of the Kingdom of Saudi Arabia 2030 vision from their point of view. Arabic Studies in Education and Psychology, 111, 199-218. 
Education and Training Evaluation Authority (2019). PISA international tests, retrieved from the link: https://etec.gov.sa/en/productsandservices/Qiyas/internationaltests/PISA/Pages/default.aspx, retrieved $12 / 28 / 1441 \mathrm{AH}$.

Khalil, Ibrahim bin Al-Hussein and Al-Maliki, Mufreh bin Masoud (2017). Factors affecting the beliefs of mathematics teachers towards their teaching competence, Journal of Mathematics Education, 20 (2), 238256.

Khalil, Ibrahim bin Al-Hussein and Al-Nazir, Muhammad bin Abdullah (2019). A proposal to include community mathematics in the series of mathematics books for the higher elementary stage in the Kingdom of Saudi Arabia. Journal of Pedagogical Mathematics, 22 (2), 285-315.

Khalil, Ibrahim bin Al Hussein. (2016). Teaching practices for teachers of mathematics in the classroom and upper secondary stage in the components of mathematical strength. Journal of the Message of Education and Psychology, (54), 151-172.

Mersal, Ikrami (2016). The level of mathematical education among students. Mathematics teachers in the General Diploma Program at the Faculty of Education: An analytical study.

Obaid, William (2016). Teaching mathematics to all children in light of the requirements of standards and the culture of thinking, Amman: Dar Al-Masirah.

Obeida, Nasser Al-Sayed Abdel-Hamid (2017). The effectiveness of a teaching model based on PISA activities in developing the components of athletic prowess and sports confidence among first-grade secondary students. Journal of Studies in Curricula and Teaching Methods, (219), 13-70.

Oshoush, Ibrahim Mohamed (2015). The extent of the consistency of primary school mathematics teachers' beliefs and classroom practices regarding the use of learning by playing. Journal of Pedagogical Mathematics, 18 (7), 6-53.

Tarawneh, Awad Faiq and Khasawneh, Amal Abdullah (2018). Mathematics teachers' beliefs and their relationship to their teaching practices, Educational Sciences Studies, 45 (4), 290-310.

Tarawneh, Awad Faiq and Khasawneh, Amal Abdullah (2018). Mathematics teachers' beliefs and their relationship to their teaching practices, Educational Sciences Studies, 45 (4), 290-310.

Ambarita, S. ; Asri, L. ; Agustina, A. ; Octavianty, D. \&Zulkardi.(2018). Mathematical Modeling Skills on Solving PISA Problems. Journal of Physics: Conference Series, 1097.

Cross, D. (2009). Alignment, cohesion, and change: Examining mathematics teachers' belief structures and their influence on instructional practices. Journal of Mathematics Teacher Education, 12, 325- 346.

Kim, R. ; Sihn, H. ; Mitchell, R. (2014). South Korean Elementary Teacher' Mathematics Teaching Efficacy Beliefs: Implications for Educational Policy and Research. Mathematics Educations Trend and Research. 1-17. Available at: http://www.ispacs.com/journals/metr/2014/metr-00052.

León-Mantero, C; Pinto, N; Camino, A; \&Fernández-Cézar, R. ( 2020).Dominioafectivo y prácticasdocentes en EducaciónMatemática: un estudioexploratorio en maestros. UNION. 58. Pp 129-149.

Melody, G; Ariadna, G; Natalia, S; \& Raquel, F. (2020). Las creencias de los futuros maestros sobre la enseñanza y aprendizaje de lasmatemáticas.REVISTA ESPACIOS. 41(9). p14.

Neidorf,T; Binkley, M; Gattis, K; Nohara,D. ( 2006). Comparing Mathematics Content in the National Assessment of Educational Progress (NAEP), Trends in International Mathematics and Science Study (TIMSS), and Program for International Student Assessment (PISA) 2003 Assessments Technical Report . U.S. Department of Education Institute of Education Sciences NCES 2006-029.

OECD (2013), PISA 2012 Assessment and Analytical Framework: Mathematics, Reading, Science, Problem Solving and Financial Literacy, OECD Publishing. http://dx.doi.org/10.1787/9789264190511-en.

OECD (2019), PISA 2018 Assessment and Analytical Framework, PISA, OECD Publishing, Paris, https://doi.org/10.1787/b25efab8-en.

Rizki, L. ; Priatna, N. (2019). Mathematical literacy as the 21st century skill. Journal of Physics: Conference Series, 1157 